Indonesian Journal of Nutrition and Dietetics Vol. 6, Issue 1, 2018: 23-27
Available online at: http://ejournal.almaata.ac.id/index.php/IJND

DOI : http://dx.doi.org/10.21927/ijnd.2018.6(1).23-27

\title{
Substitution of rice brand had the impact on organoleptic properties and nutritional value of yogurt
}

\author{
Choirun Nisa1 ${ }^{1}$, Veriani Aprilia ${ }^{1}$, Lana Santika Nadia² \\ ${ }^{1}$ Departement of Nutrition, Faculty of Health Sciences, Universitas Alma Ata, \\ Jl. Brawijaya No. 99 Tamantirto Yogyakarta, 55183 Indonesia, Telephone (+6274) 4342288 Fax: (+6274) 4342269 \\ ${ }^{2}$ Department of Food Technology, Faculty of Agriculture, Univeristas Gadjah Mada Yogyakarta, Indonesia \\ *corresponding author: apri@almaata.ac.id
}

\begin{abstract}
ABSTRAK
Latar Bekalang: Indonesia dikenal sebagai negara agraris, beras merupakan makanan pokok warganya, dengan setiap tahun mampu memproduksi beras yakni 32 juta ton. Bekatul beras merupakan limbah hasil penggilingan padi yang biasanya digunakan sebagai pakan hewan, sebagai pangan fungsional mengandung banyak zat gizi yaitu protein, lemak, karbohidrat, serat kasar dan vitamin B1, namun konsumsinya masih rendah karena kandungan lemak yang tinggi menyebabkan mudah rusak, kurang tahan lama dan berbau tengik, sehingga perlu dilakukan versivikasi pangan guna meningkatkan konsumsi bekatul salah satunya dengan ditambahkan ke yogurt. Yogurt merupakan produk fermentasi susu dengan bakteri Lactobacillus bulgaricus dan Streptococcus thermophiles berikut manfaatnya yaitu sebagai sumber kalsium, anti bakteri, untuk mengurangi kolesterol, dan penderita obesitas.

Tujuan: Untuk mengetahui pengaruh substitusi tepung bekatul terhadap sifat organoleptik dan nilai zat gizi pada produk yogurt bekatul.

Metode: Jenis penelitian adalah eksperimental dengan menggunakan RAL (Racangan Acak Lengkap) dengan 4 perlakuan dan 2 kali ulangan. Sampel dalam penelitian ini adalah yogurt bekatul dengan formula yaitu PO (175 g susu UHT: 0\% bekatul), P1 (165 g susu UHT: 5\% bekatul), P2 (155 g susu UHT: 10\% bekatul), P3 (145 g susu UHT: 15\% bekatul). Pada sifat organoleptik (uji kesukaan) yaitu dari rasa, aroma, tekstur, warna dan keseluruhan. Pada analisis nilai gizi yang diukur meliputi kadar air, abu, protein, lemak, karbohidrat, serat, gula reduksi, dan gula total.

Hasil: Berdasarkan pengujian sifat organoleptik atau uji kesukaan yogurt substitusi tepung bekatul pada atribut warna, rasa, aroma dan keseluruhan, yogurt bekatul P1 (165 g susu UHT: 5\% tepung bekatul) paling disukai panelis. Dari hasil pengujian nilai gizi yogurt bekatul P3 (145 g susu UHT: 15\% bekatul) memiliki kadar abu, protein, lemak dan serat, gula total paling tinggi. Namun kadar air, karbohidrat, dan gula reduksi paling rendah.

Kesimpulan: Makin banyak substitusi tepung bekatul, maka makin tinggi nilai gizi yogurt bekatul. Namun kesukaan panelis terhadap yogurt bekatul makin rendah.
\end{abstract}

Kata Kunci: yogurt bekatul, sifat organoleptik, nilai gizi

\begin{abstract}
Background: Indonesia is known as an agricultural country, rice is the staple food of citizens, each year capable of producing 32 million tons of rice. Rice bran was a waste of rice mill which is usually used as animal feed, as functional food contains many nutrients such as protein; fat; carbohydrate; crude fiber; and vitamin B1, but the consumption is still low because the high fat content causes easily damaged, less durable, and rancid smell. So, it is necessary to do food diversification to increase bran consumption, such as by addition to yogurt. Yogurt is a fermented milk product from Lactobacillus bulgaricus bacteria and Streptococcus thermophilus along with its benefits as a source of calcium, anti-bacterial, reducing cholesterol, and lowering of body weight.

Objectives: To know the effect of rice bran substitution on organoleptic properties and nutritional value of rice bran yoghurt products.

Methods: The study was experimental used complete randomized design with 4 treatments and 2 replications. The sample of this research was rice bran yoghurt with formula that were PO (175 g of milk
\end{abstract}


UHT: 0\% bran), P1 (165 g of UHT milk: 5\% bran), P2 (155 g of UHT milk: $10 \%$ bran), P3 (145 g UHT milk: $15 \%$ bran). Organoleptic properties (hedonic test) were analyzed from the taste, aroma, texture, color, and overall; whereas nutritional values measured were moisture, ash, protein, fat, carbohydrate, fiber, reducing sugar, and total sugar contents.

Results: Based on organoleptic properties test in all parameters, $P 1$ formula was most preferred by panelists. However, the highest of protein, fat, fiber content, and total sugar was obtained from formula of $P 3$. Conclusions: The more substitution of rice bran into the yogurt, the higher nutritional value, although the panelist's preference was getting lower.

KEYWORDS: nutritional value, organoleptic properties, rice bran, yoghurt

\section{INTRODUCTION}

Indonesia is known for the agrarian country because it is a country where most of the population works as farmers, so the agricultural sector becomes the main focus (1). Every year Indonesia is able to produce 47 million tons of rice. This amount is equivalent to the amount of rice production, which is 32 million tons per year (2). Production from agricultural sector that is not less abundant in Indonesia is rice bran. Rice bran is a waste of grinding or gushing or rice which is usually used as animal feed. Inside the bran is contained several nutrients, namely protein (13-17\%), fat $(2.5-5 \%)$, carbohydrates $(67-72 \%)$, crude fiber (371-387 calories) and rich in vitamin B1 (thiamin) (3). The amount of nutrient content in bran causes bran is easily damaged by microbes and enzymes (4).

Despite having a good nutritional content, rice bran consumption is still very low. This was due to unpleasant taste (langu, in bahasa) and less interested (5). Some researchers conducted research to improve the utilization of bran, among others, cookies (3), tempeh (6), wet noodles (7) and milk (8). However, the product can not last long storage because of the hydrolytic and oxidative activity of the lipase (7). One of the product development to overcome that is yogurt. Yogurt is a fermented milk that can lower cholesterol (9) boost immunity regulating the digestive system and boost the immune system (10).

Zubaidah (11) used rice bran in the manufacture of yogurt with the addition of rice bran $0 \%, 4 \%, 8 \%$, and $12 \%$ using Lactobacillus casei bacteria. The results indicated that the more bran added to the yogurt, the higher lactic acid bacteria and acidity due to the content of phytochemical compounds and fiber content as a prebiotic that could increase the viability of probiotics. In addition, the higher the bran added, the higher the inhibiting activity of pathogenic bacteria Staphylococcus aureus.

Based on the above background, it is necessary to do research on the effect of rice bran substitution on the level of favorite and nutritional value of yogurt. This research studied about the substitution of rice bran with the concentration of $0 \%, 5 \%, 10 \%$, and $15 \%$.

\section{MATERIALS AND METHOD}

Rice bran was obtained from local market in Yogyakarta. It was then added to the yogurt and replace the content of milk in yogurt. The samples in this research were yogurt with 4 concentration of rice flour $0 \%, 5 \%, 10 \%$, and $15 \%$.

This experimental study used a complete randomized design and conducted in April 2017 at the biomedical laboratory and culinary laboratory of Universitas Alma Ata Yogyakarta for organoleptic testing, while nutritional value analysis was done at the Laboratory Center between University biotechnology Gadjah Mada University.

The variables of this research were substitution of bran flour $(0 \%, 5 \%, 10 \%, 15 \%)$ as independent variable and dependent variable were organoleptic properties (favorite test) dependent variable. We used semi-trained panelists as many as 25 people taken from Department of Nutrition students who had received sensory test lectures.

The method used in testing of organoleptic properties was hedonic test, while the method of nutritional value analysis were water and ash 
content analysis using thermogravimetry, protein analysis with micro-Kjeldahl, fat analysis with soxhlet, carbohydrate analysis with carbohydrate by difference, analysis of crude fiber with gravimetry and total sugar and reduction with Nelson-Somogy method.

\section{RESULTS AND DISCUSSION}

\section{Organoleptic properties test}

Based on Table 1, the panelists preferred flavor and aroma yogurt that was substituted with less than or equal $5 \%$ of rice bran, while on the color attribute, texture and overall, panelists preferred yogurt without substitution of rice bran or control. This was related to the substitution composition of bran flour given. The higher the substitution of rice bran, the lower the level of preference of yogurt. It may be due to the unpleasant aroma of rice bran and its viscous texture that affected the level of acceptance.

Table 1. The influence of rice bran substitution on organoleptic properties of yogurt

\begin{tabular}{lcccc}
\hline \multirow{2}{*}{ Attribute } & \multicolumn{4}{c}{ Rice bran substitution } \\
\cline { 2 - 5 } & $\mathbf{0 \%}$ & $\mathbf{5 \%}$ & $\mathbf{1 0 \%}$ & $\mathbf{1 5 \%}$ \\
\hline Appearance & $2.8^{\mathrm{a}}$ & $2.3^{\mathrm{ab}}$ & $1.9^{\mathrm{b}}$ & $1.8^{\mathrm{b}}$ \\
Color & $5.7^{\mathrm{a}}$ & $4.4^{\mathrm{b}}$ & $3.6^{\mathrm{bc}}$ & $3.1^{\mathrm{c}}$ \\
Flavour & $4.8^{\mathrm{a}}$ & $4.2^{\mathrm{a}}$ & $2.6^{\mathrm{b}}$ & $2.5^{\mathrm{b}}$ \\
Texture & $4.9^{\mathrm{a}}$ & $3.8^{\mathrm{b}}$ & $3.2^{\mathrm{b}}$ & $3.0^{\mathrm{b}}$ \\
Overall & $5.1^{\mathrm{a}}$ & $4.0^{\mathrm{b}}$ & $3.0^{\mathrm{c}}$ & $2.3^{\mathrm{c}}$ \\
\hline
\end{tabular}

Notes: The different superscript within the same row showed significant difference $(p<0.05)$. Values describes the level of preferences which ranked from 1-6 for the less preference-most preference

\section{Nutrition value analysis}

Based on Table 2. It shows that generally, rice bran substitution on ash, protein, fat, fiber and total sugar increased the nutritional value of yogurt. This was due to the substance of rice bran that contained of ash $1.8 \%$, protein $3.2 \%$, fat $1.0 \%$, high fiber of $7.7 \%$, and total sugar $2.4 \%$.

In other research, in $100 \mathrm{~g}$ of rice bran, it consisted of $14.5-15.7 \mathrm{~g}$ of protein, $2.94 \mathrm{~g}$ of fat, 6.8 to $10.4 \mathrm{~g}$ of crude fiber, $50.7 \mathrm{~g}$ of carbohydrates, $59.2 \mathrm{~g}$ of thiamine (vitamin B1) $319 \mathrm{mg}$, of riboflavin (vitamin B2), and 224-389 mg of niacin (12). In addition, vitamins such as carotene $(4.2 \mu \mathrm{g} / \mathrm{g})$, thiamin $(10.1-27.9 \mu \mathrm{g} / \mathrm{g})$, riboflavin $(1.7-3.4 \mu \mathrm{g} / \mathrm{g})$, niacin $(236-590 \mu \mathrm{g} / \mathrm{g})$, pyridoxine $(10.3-32.1 \mu \mathrm{g} / \mathrm{g})$, pantothenic acid $(27.7-71.3 \mu \mathrm{g} / \mathrm{g})$, biotin $(0.16$ to $0.60 \mu \mathrm{g} / \mathrm{g})$, inositol $(4,62-9.27 \mu \mathrm{g} / \mathrm{g})$, choline (1.28$1.70 \mu \mathrm{g} / \mathrm{g})$, folic acid $(0.5-1.46 \mu \mathrm{g} / \mathrm{g})$, vitamin B12 $(0.005 \mu \mathrm{g} / \mathrm{g})$ and tocopherol (149.2 $\mu \mathrm{g} / \mathrm{g})(13)$.

Protein content is closely related to the composition of the ingredients. This was related to high bran protein, according to Wulandari (14) which states that bran contained a high enough protein $(14.34 \%)$. Yogurt protein content was also influenced by protein content of raw milk, the higher the milk protein content then the yogurt protein content is also high. When compared with milk protein content ranging from $2.26-2.58 \%$, the yogurt protein content of the research results was higher. Bacteria contain high enough protein, based on dry weight about $60-70 \%$. This bacterial protein accounts for about $7 \%$ of the total milk protein of fermentation (15). And also the calculation of protein research using $\mathrm{N}$-Total protein.

Fat content and bran yoghurt fiber were associated with high fat and fiber content in bran $10,1-12,4 \%$ (5) and $21-27 \%$ (16) so that the composition of the material was very closely related to fat and fiber content

Table 2 shows that the total sugar content was closely related to Kumalasari research (17) that lactic acid yogurt bacteria can only utilize sugar derived from milk or it can be said that lactic acid bacteria could achieve maximum activity if using milk media. Kumalasari research (18) also stated that lactose was a source of energy for lactic acid bacteria in the fermentation process. It meant that the material composition of UHT milk affected the increase of total sugar content.

Substitution of bran flour decreased the moisture, carbohydrate and reducing sugars by each level of $75.6 \%, 5.3 \%$, and $0.7 \%$. On the assessment of the water content of bran yogurt was very closely related to the bran which has the water binding properties (11), so the higher the substitution of bran flour, the lower the water content.

On the assessment of carbohydrates related to the calculation of carbohydrate yogurt bran. 
Carbohydrate by diference was obtained from calculations of reduction of water content, ash, fat and protein (19). With the reduction of the amount of nutrient content that each high, causing low carbohydrate levels. At reducing sugar levels associated with the composition of UHT milk ingredients used as lactose sources broken down by lactic acid bacteria to lactic acid. Thus, the higher the substitution of bran flour, the higher the nutritional value of bran yogurt.

Table 2. Nutritional value analysis results of bran yoghurt

\begin{tabular}{lcccc}
\hline \multirow{2}{*}{$\begin{array}{c}\text { Content } \\
\text { (\%) }\end{array}$} & \multicolumn{4}{c}{ Rice bran substitution } \\
\cline { 2 - 5 } & $\mathbf{0 \%}$ & $\mathbf{5 \%}$ & $\mathbf{1 0 \%}$ & $\mathbf{1 5 \%}$ \\
\hline Water & $86.8^{\mathrm{a}}$ & $83.3^{\mathrm{b}}$ & $79.9^{\mathrm{c}}$ & $75.6^{\mathrm{d}}$ \\
Ash & $1.0^{\mathrm{a}}$ & $1.2^{\mathrm{b}}$ & $1.5^{\mathrm{c}}$ & $1.8^{\mathrm{d}}$ \\
Protein & $1.6^{\mathrm{a}}$ & $2.2^{\mathrm{b}}$ & $2.7^{\mathrm{c}}$ & $3.2^{\mathrm{d}}$ \\
Fat & $0.6^{\mathrm{a}}$ & $0.7^{\mathrm{b}}$ & $0.9^{\mathrm{c}}$ & $1.0^{\mathrm{d}}$ \\
KH & $133^{\mathrm{a}}$ & $8.3^{\mathrm{b}}$ & $6.3^{\mathrm{c}}$ & $5.3^{\mathrm{c}}$ \\
Fiber & $5.1^{\mathrm{a}}$ & $6.0^{\mathrm{b}}$ & $6.7^{\mathrm{c}}$ & $7.7^{\mathrm{d}}$ \\
Reductive sugar & $0.9^{\mathrm{a}}$ & $0.8^{\mathrm{b}}$ & $0.8^{\mathrm{b}}$ & $0.4^{\mathrm{c}}$ \\
Total Sugar & $0.4^{\mathrm{a}}$ & $3.8^{\mathrm{b}}$ & $3.8^{\mathrm{b}}$ & $2.4^{\mathrm{c}}$ \\
\hline
\end{tabular}

Notes: The different superscript within the same row showed significant difference $(p<0.05)$. Based on the code that the nutritional value of substituted yogurt flour significantly different from the control.

\section{CONCLUSIONS AND RECOMMENDATIONS}

From the results above, it can be concluded that there was the effect of rice bran substitution on the organoleptic properties of yogurt. Based on all observed organoleptic properties parameters, color, flavor, aroma and whole substitution from the substitution of $5 \%$ rice bran is the best characteristic treatment, preferably panelist, and has the highest alternative value. There was also the influence of rice bran substitution on nutritional value (water, ash, protein, fat, fiber, and total sugar) with the highest impact when rice bran substituted in the level of $15 \%$, although the water content, carbohydrate levels, and sugar reduction was the lowest.

For recommendation, there needs to be further research on the substitution of bran flour or other additions with the same or different percentages to know the more influences. It was also need to be developed further about making yogurt with substitution or the addition of different materials so that the smell become pleasant. Utilization of bran as nutritious food has not been done, so for the future research, it is expected that bran can be an alternative food good for health.

\section{REFERENCES}

1. Iriyani, N. Sereal Pangan Subtitusi Bekatul Tinggi Oksidan. Artikel Penelitian. 2011. Semarang : Universitas Diponegoro.

2. Sanny, L. Analisis Produksi Beras di Indonesia. Binus Business Review. 2010. 1 (1) : 245-251

3. Wulandari, M dan Handasari, E. Pengaruh Penambahan Bekatul terhadap Kadar Protein dan Sifat Organoleptik Biskuit. Jurnal Pangan dan Gizi. 2010 ; 1 (2) : 55-62

4. Widyastuti, L. A., Wahyu, A. N. Adhy, P. R. OatsBekatul Sebagai Pangan Fungsional. [Skripsi] Yogyakarta : Universitas Negeri Yogyakarta ; 2010.

5. Natalianingsih. Analisis Kandungan Gizi dan Sifat Organoleptik terhadap Bekatul. [Skripsi]. Bandung : Universitas Bandung Raya ; 2010.

6. Lusiyatiningsih, T. Uji Kadar Serat Protein dan Sifat Organoleptik pada Tempe dari Bahan Dasar Kacang Merah (Phoseolus Vulgarius $L$ ) dengan Penambahan Jagung dan Bekatul. [Skripsi]. Surakarta : Universitas Muhammadiyah Surakarta ; 2014

7. Fitrianingsih, E., Ampera, M., Suryana. Pemanfaatan Tepung Bekatul terhadap Daya Terima Mie Basah. [Skripsi]. Aceh : Poltekes Aceh ; 2010.

8. Murtisari, D. Kandungan Vitamin B1 Dan Kualitas Yoghurt Susu Bekatul Dengan Variasi Lama Pemanasan Dan Penambahan Susu Sapi Murni Yang Berbeda. [Skripsi]. Surakarta: Universitas Muhammadiyah Surakarta ; 2015.

9. Riyanto, S., Hesti, M. R. Yoghurt Kedelai Hitam (black soyghurt) dapat menurunkan kadal LDL tikus hiperkoleterolemia. Jurnal Gizi dan Dietetik Indonesia ; 2015.3 (1) : 1-9

10. Surajudin, Fauzi, R. Kusuma dan Dwi P. Susu Fermentasi yang Menyehatkan. Jakarta : Penebar Swadaya ; 2005. 
11. Zubaidah, E. 2006. Pengembangan Pangan Probiotik Berbasis Bekatul. Jurnal Tekhnologi Pertanian. Vol. 7 No. 2.

12. Winarno. Pengantar Tekhnologi Pangan. Jakarta : Gramedia Pustaka Utama ; 2010

13. Damaryanthi, E. Karakteristik Bekatul Padi (Oriza Sativa) Awet serta Sifat Antioksidan dan Penghambat Profilerasi Sel Kanker secara In Vitro dari Minyak dan Fraksinya [Disertasi] Bogor : IPB ; 2002.

14. Wulandari, P. A., I Ketut, S., Nengah, K. P., I Wayan, R. W. Bekatul Beras Merah Sebagai Salah Satu Alternatif Sumber Antioksidan. [Skripsi] Bali : Universitas Udayana ; 2011

15. Widayati, W. Sifat Fisikokimia dan Total Bakteri Asam Laktat (BAL) pada Yogurt Bekatul. [Skripsi]. Yogyakarta : Universitas Alma Ata Yogyakarta ; 2017.
16. Iriyani, N. Sereal Dengan Subtitusi Bekatul Tinggi Antioksidan. [Skripsi]. Semarang : Universitas Diponegoro : 2011.

17. Kumalasari, K.E.D., Nurwantoro, Mulyani, S. Pengaruh Kombinasi Susu dengan Air Kelapa terhadap Total Bakteri Asam Laktat (BAL), Total Gula dan Keasaman Drink Yoghurt. Jurnal Aplikasi Tekhnologi Pangan. 2012 ; 1 (2) : 48-53.

18. Kumalasari, K.D., Anang, M.L., Ahmad, N.A. Total Bakteri Asam Laktat, Kadar Laktosa, pH, Keasaman, Kesukaan Drink Yogurt dengan Penambahan Ekstrak Buah Kelengkeng. Jurnal Aplikasi Tekhnologi Pangan. 2013 ; 2 (4) : 165168.

19. Saleh, E. Tekhnologi Pengolahan Susu dan Hasil Ikutan Ternak. 2004. Tersedia dalam http:// library.usu.ac.id/download/fp/ternak-eniza.pdf [Diakses pada 24 Juli 2017 pk. 16.22 wib]. 